\title{
The Legal and Policy Implications of the US Steel Tariffs on East Asia
}

\author{
John Riley*
}

\begin{abstract}
Many are crying foul over the Trump Administration's use of steel and aluminum tariffs, claiming that imports are not a threat to the US national security. Rather, it has been argued that the tariffs are a pretext to gain strategic advantage in unrelated trade negotiations. Members of the Trump administration have hailed subsequent trade concessions as proof that the tariffs have been successful, which, if proven, could raise a credible question as to whether the President exceeded the scope of his authority. Domestic and international challenges have already begun with the US courts being a more effective forum to the challenge the legality of the tariffs than the WTO.
\end{abstract}

\section{Keywords}

Donald Trump, US Steel, Tariffs, National Security, WTO, Section 232

\section{Introduction}

Shortly following the 2016 US election, President Trump instructed Secretary of Commerce Wilbur Ross to initiate a Section 232 investigation under the Trade Expansion Act of $1962^{1}$ to determine the effects of steel imports on the US national security. ${ }^{2}$ A Section 232 investigation requires the Secretary of Commerce to provide

* Assistant Professor of Law at Sogang University School of Law. J.D. (Pittsburgh). ORCID: http://orcid.org/0000-00027512-9090. The author may be contacted at: johnriley007@gmail.com / Address: Sogang University School of Law, 35 Baekbeom-ro (Sinsu-dong), Mapo-gu, Seoul 04107 Korea.

19 U.S.C. $\$ 1862(\mathrm{~b})(1)(\mathrm{A})$.

2 See Remarks by President Trump at Signing of the Memorandum regarding the Investigation Pursuant to Section 232(B) of the Trade Expansion Act (Apr. 20, 2017), available at https://www.whitehouse.gov/briefings-statements/ remarks-president-trump-signing-memorandum-regarding-investigation-pursuant-section-232b-trade-expansion-act. The following week, a second investigation was initiated on imports of aluminum. See Presidential Memorandum for the Secretary of Commerce, The White House (Apr. 27, 2017), available at https://www.whitehouse.gov/presidentialactions/presidential-memorandum-secretary-commerce (all last visited on Apr. 21, 2018).

DOI: http://dx.doi.org/10.14330/jeail.2018.11.1.10 
notice $^{3}$ to and consult with the Secretary of Defense, ${ }^{4}$ and to issue a report on the findings of the investigation to the President within 270 days. ${ }^{5}$ Within 90 days after receiving the Secretary's report, the President must determine which action, if any, will be taken against an import determined by the Secretary to be a national security threat, ${ }^{6}$ and to submit a written statement to Congress, identifying the reasons for taking or refusing to action against a particular item. ${ }^{7}$ If the President determines to take action against a particular import, he must do so within 15 days of making such a determination. ${ }^{8}$

In determining whether an imported article poses a national security threat to the US, the statute requires the Secretary and President to give consideration to:

- domestic production needed for projected national defense requirements;

- domestic industry's capacity to meet those requirements;

- related human and material resources;

- the importation of goods in terms of their quantities and use;

- the close relation of national economic welfare to U.S. national security;

- loss of skills or investment, substantial unemployment and decrease in government revenue; and

- the impact of foreign competition on specific domestic industries and the impact of displacement of any domestic products by excessive imports. ${ }^{9}$

On January 11, 2018, the Secretary of Commerce submitted its report, ${ }^{10}$ which issued the following findings:

- Steel is important to the US national security. National security includes projected defense requirements for the Department of Defense, as well as critical infrastructure such as transportation, the electric power grid, water systems and energy generation

319 U.S.C. $§ 1862(b)(1)(B)$. See W. Ross, Section 232 Notification Letter to Secretary of Defense James Mattis, US Dept. of Commerce (Apr. 19, 2017), available at https:/www.commerce.gov/sites/commerce.gov/files/media/ files/2017/2017-04-19_2.pdf (last visited on Apr. 21, 2018).

419 U.S.C. $\$ 1862(\mathrm{~b})(2)(\mathrm{A})(\mathrm{i})$.

$5 \quad I d . \S 1862(\mathrm{~b})(3)(\mathrm{A})(\mathrm{i})$.

$6 \quad$ Id. $\S 1862(\mathrm{c})(1)(\mathrm{A})$.

$7 \quad I d . \S 1862(\mathrm{c})(2)$.

$8 \quad I d . \S 1862(\mathrm{c})(1)(\mathrm{B})$.

$9 \quad$ Id. $\$ 1862(\mathrm{~d})$.

10 US Dept. of Commerce Office of Technology Evaluation, The Effect of Imports of Steel On the National Security: An Investigation Conducted Under Section 232 of the Trade Expansion Act of 1962, As Amended, Jan. 11, 2018, available at https://www.commerce.gov/sites/commerce.gov/files/the effect of imports of steel on the national security - with redactions - 20180111.pdf (last visited on Apr. 21, 2018). 
systems. Domestic steel production is essential for national security applications and depends on a health and competitive US industry, including mills with basic oxygen furnaces, mini-mills using electric arc furnaces, re-roller/converter, and metal coater facilities, which produce steel products that are used in five categories used in national security applications, including flat, long, semi-finished, pipe and tube and stainless. $^{11}$

- Current Imports Adversely Impact the US Steel Industry. The US is the world's largest importer of steel, accounting for 30 percent of the US consumption. Additionally, excessive imports lower prices, which have resulted in the closure of numerous steel mills, a rise in unemployment, and lost market share. ${ }^{12}$

- Excessive imports weakens the internal economy. The US steel production has decreased, which has led to the closure of six basic oxygen furnace facilities and the idling of four more (over 50 percent of total facilities), a 35 percent loss of employment, and a negative net income since 2009, resulting in a capacity utilization rate that is not economically sustainable. $^{13}$

- Global excess steel contributes to the weakening of the US Economy. Free markets of the world are adversely affected by global excess steel production led by China, which is able to produce more steel than the rest of the world combined, causing other countries to export more steel to the US to offset losses in other markets with significant Chinese steel exports. ${ }^{14}$

Based on these findings, the Secretary made the following recommendations to the President to impose:

- a global quota on all steel products from all countries equal to $63 \%$ of each country's 2017 exports to the US. ${ }^{15}$

- a global tariff of at least $24 \%$ on all steel imports from all countries; ${ }^{16}$ or

- a tariff of at least $53 \%$ on all steel imports from 12 countries (Brazil, China, Costa Rica, Egypt, India, Malaysia, Republic of Korea, Russia, South Africa, Thailand, Turkey and Vietnam) with a quota by product on steel imports from all other countries equal to $100 \%$ of their 2017 exports to the US. ${ }^{17}$

The President concurred with the report and, on March 8, 2018, issued Proclamation

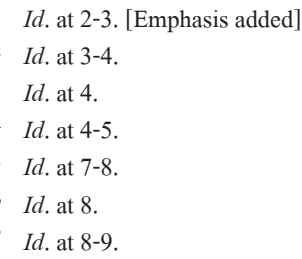


No. 9705, which imposed a 25 percent ad valorem tariff on steel imports for all countries except Canada and Mexico to take effect March 23, 2018. ${ }^{18}$ Proclamation 9705 allowed for businesses to apply for exclusions for particular steel products not available in the US in a "sufficient and reasonably available amount or of a satisfactory quality," 19 as well as country-wide exemptions for certain countries which have security relationships with the US and where a "satisfactory alternative means to address the threat to the national security" is agreed upon. ${ }^{20}$ The Commerce Department published instructions for how US domestic businesses could apply for product-based exclusions for the import of steel, ${ }^{21}$ but left country-wide exemptions to be negotiated on a case-by-case basis. ${ }^{22}$ On March 22, 2018, the President issued an additional proclamation indicating that the government was in the process of negotiating "satisfactory alternative means" to steel tariffs with countries having important security relationships with the US, including, Australia, Argentina, Korea, Brazil and members of the European Union. ${ }^{23}$ The country-wide exemptions based on security relationships were limited until May 1, 2018, which could be extended by further negotiation. ${ }^{24}$ As of April 2018, preliminary agreements with certain countries have been reported, while others have yet to agree. For example, the South Korean government has reportedly agreed to adhere to an annual quota of 2.68 million tons of steel exports to the US, and has also agreed to extend preferential trade benefits to the American automakers under the US-Korea Free Trade Agreement. ${ }^{25}$

Not surprisingly, the US steel manufacturers overwhelmingly approved of

18 Proclamation 9705, 83 Fed. Reg. No. 51, at 11,625-11,627 (Mar. 15, 2018), available at https://www.federalregister. gov/documents/2018/03/15/2018-05478/adjusting-imports-of-steel-into-the-united-states (last visited on Apr. 21, 2018).

19 Id. at $11,627$.

20 Id. at $11,626$.

21 Requirements for Submissions Requesting Exclusions from the Remedies Instituted in Presidential Proclamations Adjusting Imports of Steel into the United States and Adjusting Imports of Aluminum into the United States; and the Filing of Objections to Submitted Exclusion Requests for Steel and Aluminum, 83 Fed. Reg. 12,106, 12109 (Mar. 19, 2018), available at https://www.federalregister.gov/documents/2018/03/19/2018-05761/requirements-for-submissionsrequesting-exclusions-from-the-remedies-instituted-in-presidential (last visited on Apr. 21, 2018).

22 Id. at 12,108. It reads: "The process described above for the two new supplements is separate and apart from the process by which countries may seek exemptions from the duties imposed by the President."

23 Proclamation 9711, 83 Fed. Reg. No. 60, 13,361 (Mar. 22, 2018), available at https://www.gpo.gov/fdsys/pkg/FR2018-03-28/pdf/2018-06425.pdf (last visited on Apr. 21, 2018).

24 Id. at $13,362-13,364$.

25 A. Rappeport \& J. Tankersley, Trump Gets First Major Trade Deal as South Korea Looks to Avoid Tariffs, N.Y. TIMES, Mar. 26, 2018, available at https://www.nytimes.com/2018/03/26/business/south-korea-us-tariffs.html. See also ROK Ministry of Trade, Industry and Energy, Korea, US reach agreement on trade deal and steel tariff exemption, Press Release, Mar. 26, 2018, available at $\mathrm{http} / /$ english.motie.go.kr/en/pc/photonews/bbs/bbsList.do?bbs_cd_n=1\&bbs seq $n=678$ (all last visited on Apr. 21, 2018). 
the tariffs. US Steel CEO, David Burritt, thanked the Trump administration for its 'courageous leadership' on tariffs, stating that the strength of the US depended on the steel tariffs for a large manufacturing base. ${ }^{26}$ The company's stock price has traded over USD 45 a share since the announcement, up from a low of under USD 20 in the summer of 2017, and USD 7 per share in $2016 .^{27}$ The Trump administration has downplayed the negative effects of the tariffs. Secretary of Commerce Ross argued that criticism of the tariffs is "a lot to do about nothing" which will not seriously impact consumer purchases. He said:

People talk about cars. There's about one ton of steel in a car, and the price of a ton of steel is $\$ 700$ or so. So $25 \%$ on that would be [a] one half of $1 \%$ price increase, on a typical $\$ 35,000$ car, he said. "So it's no big deal.,"28

The tariffs have been roundly criticized by the US steel-consuming industries and business groups. For example, the American Automotive Policy Council, an association that represents automakers such as Form and GM, issued a statement regarding the tariffs:

We are concerned with the unintended consequences the proposals would have, particularly that it will lead to higher prices for steel and aluminum here in the United States, compared to the price paid by our global competitors. This would place the U.S. automotive industry, which supports more than 7 million American jobs, at a competitive disadvantage. $^{29}$

Other business groups such as the US Chamber of Commerce echoed these concerns, highlighting the ineffectiveness of the tariffs, how they would harm the US importers, as well as the prospect of retaliation from other countries:

These new tariffs would directly harm American manufacturers, provoke widespread retaliation

26 B. Lovelace Jr., US Steel CEO: We're reopening an idled plant and bringing back 500 jobs due to Trump tariffs, CNBC, Mar. 7, 2018, available at https://www.cnbc.com/2018/03/07/us-steel-reopening-plant-and-bringing-back-jobsceo-on-trump-tariffs.html (last visited on Apr. 21, 2018).

27 Staff reporter, United States Steel Corp (X.N), ReuTERS, available at https://www.reuters.com/finance/stocks/chart/X.N (last visited on Apr. 21, 2018).

28 J. Horowitz, Wilbur Ross defends Trump tariffs with a can of Campbell's soup, CNN, Mar. 2, 2018, available at http:// money.cnn.com/2018/03/02/news/economy/wilbur-ross-soup-cnbc-interview/index.html (last visited on Apr. 21, 2018).

29 AAPC, AAPC Statement on U.S. Commerce Department's 232 Reports on Steel and Aluminum, Feb. 16, 2018, available at $\mathrm{http} / /$ www.americanautocouncil.org/content/aapc-statement-us-commerce-departments-232-reports-steeland-aluminum (last visited on Apr. 21, 2018). [Emphasis added] 
from our trading partners, and leave virtually untouched the true problem of Chinese steel and aluminum overcapacity. Alienating our strongest global allies amid high-stakes trade negotiations is not the path to long-term American leadership. ${ }^{30}$

Similarly, many Republicans are ideologically opposed to trade barriers and wary about starting a global trade war. In a dramatic departure, Republican House Speaker Paul Ryan, who has worked closely with the Trump Administration on a number of legislative items such as a USD 1.5 trillion tax cut last year, broke with President Trump in a very public manner. He said: "We are extremely worried about the consequences of a trade war and are urging the White House to not advance with this plan." 31

Naturally, as the steel and aluminum tariffs have not been well received internationally, several countries are even threatening retaliation on other sectors of the US exports. The EU, for example, characterized the tariffs as "a blatant intervention amount to protectionism" and is considering applying a 25 percent tariff on steel, industrial goods and agriculture, as explained by European Commission President Jean-Claude Juncker:

We will put tariffs on Harley-Davidson, on bourbon and on blue jeans-Levis ... We are here and they will get to know us. We would like a reasonable relationship to the United States, but we cannot simply put our head in the sand. ${ }^{32}$

In the beginning, China, the world's dominant steel producer, reacted cautiously to the tariffs, not only because it does not want to inflict damage to the fragile global economic recovery, but also because it only accounts for 2 percent of the US steel imports. ${ }^{33}$ However, China increased tariffs up to 25 percent on 128 US products, including pork, wine, fruits and nuts, among others, rejecting the notion that it would

30 US Chamber of Commerce, U.S. Chamber's Donohue Comments on Prospects of Trade War, Press Release, Mar. 7, 2018, available at https:/www.uschamber.com/press-release/us-chamber-s-donohue-comments-prospects-trade-war (last visited on Apr. 21, 2018). [Emphasis added]

31 A. Swanson, Ryan Criticizes Tariff Plan as Trump Issues Nafta Threat, N.Y. TIMEs, Mar. 5, 2018, available at https://www.nytimes.com/2018/03/05/us/politics/trump-trade-tariffs-nafta.html (last visited on Apr. 21, 2018).

32 Staff reporter, Europe targets U.S. bourbon, bikes, blue jeans for trade riposte, REUTERs, Mar. 2, 2018, available at https://www.reuters.com/article/usa-trade-europe/update-3-europe-targets-u-s-bourbon-bikes-blue-jeans-for-traderiposte-idUSL8N1QK2SZ (last visited on Apr. 21, 2018).

33 S. Denyer \& R. Noack, China grumbles at Trump's tariff move, but Europe takes aim at Harleys and bourbon, WASH. Post, Mar. 2, 2018, available at https://www.washingtonpost.com/world/china-steel-slams-trumps-stupidprotectionism-but-trade-war-is-unlikely/2018/03/02/33ec5274-1d94-11e8-98f5-ceecfa8741b6_story.html?utm _ term=.669091e935c8 (last visited on Apr. 21, 2018). 
not retaliate or only take symbolic countermeasures. ${ }^{34}$ Each time the US or China issues or threatens to issue new retaliatory measures, global stock markets have reacted sharply. ${ }^{35}$

\section{US Legal Challenges}

Considering the size of the steel market, litigation in the US courts would be inevitable. To date, one case has been already filed in the US Courts, challenging the legality of the tariffs. On March 22, 2018, Severstal Export GMBH, a sales subsidiary of a Russian steel manufacturer, filed a complaint with the US Court of International Trade against the Trump Administration alleging that the tariffs "issued purely for political and economic reasons" exceeded the scope of Congress' delegation of authority under Section 232 and were therefore unconstitutional. ${ }^{36}$ The plaintiff requested a preliminary injunction, claiming that the tariffs would cause irreparable harm in that plaintiff would have to close its US operations, require its US-based customers to pay the tariffs, or breach contracts with its US customers. ${ }^{37}$ Plaintiff alleged that the national security basis for the Proclamation is a pretext for the actual intent of the tariffs, i.e.:

President Trump's regularly stated intent, both prior to entering the Office of the President, and after assuming the Presidency, to obtain a "positive trade balance" with other countries, to "bring jobs home", and win trade wars. Because Trump did not base his decision on national security grounds as required under Section 232 in issuing the Steel Proclamation, the Proclamation is unlawful. ${ }^{38}$

On April 5, 2018, the US Court of International Trade denied the plaintiff's request

34 B. Blanchard \& T. Munroe, China hits U.S. goods with tariffs as 'sparks' of trade war fly, ReuTERs, Apr. 2, 2018, available at https://www.reuters.com/article/us-usa-trade-china/china-hits-u-s-goods-with-tariffs-as-sparks-of-tradewar-fly-idUSKCN1H81J3 (last visited on Apr. 21, 2018).

35 N. Fletcher et al., Global markets plunge as China reacts to Trump's steel tariffs, GuARDIAN, Mar. 23, 2018, available at https://www.theguardian.com/business/2018/mar/23/china-promises-to-hit-us-with-tariffs-as-stocks-plunge-amidfear-of-trade-war (last visited on Apr. 21, 2018).

36 Complaint, Severstal Export GMBH v. United States of America, Case. No. 18-00057, US Ct. Int'1 Trade (Mar. 22, 2018), available at https:/www.courthousenews.com/wp-content/uploads/2018/03/steel.pdf (last visited on Apr. 21, 2018).

37 Id. at 40.

38 Id. at $\uparrow 44$. 
for a preliminary injunction. ${ }^{39}$ The court held that plaintiffs' likelihood of success on the merits was very low because the President acted within his authority under the statute. ${ }^{40}$ The parties' arguments are instructive for what similarly situated litigants would likely claim as follows:

1. The plaintiffs did not challenge the constitutionality of the statute itself per a 1976 US Supreme Court Case ${ }^{41}$ which held a prior version of the statue to be a constitutional delegation of authority under the US Constitution.

2. Likewise, plaintiffs did not challenge with procedure followed by the Commerce Department or the President in enacting the tariff.

3. Rather, the plaintiffs argued that the only President exceeded his statutory authority.

4. The defendants argued that "the President's findings of fact and the motivations for his action are not subject to review." 42

The court rejected the defendants' contention that the President's actions are nonjusticiable outside of the framework of the Administrative Procedure Act. It rather determined: "Where statutory language limits the President, the court may review the executive's actions for 'clear misconstruction' of such limiting language." ${ }^{, 43}$ The court also rejected the defendants' contention that the plaintiffs had failed to exhaust all administrative remedies by not applying for a product-specific exclusion as permitted by the Proclamation because the plaintiffs were not arguing that a specific product should be excluded, but rather that the entire Proclamation was inviolate of the US Constitution. ${ }^{44}$ As such, the court determined that the regulatory process of applying for an exemption, to the extent that it is available to litigants, is not an appropriate forum for adjudicating such claims. ${ }^{45}$

Therefore, the court had to determine whether the President exceeded his statutory authority "by over-reading what can constitute a threat to national security," which the defendants argued was barred due to the fact that the President

39 Severstal Export GMBH v. United States of America, Opinion Denying Motion for Preliminary Injunction, Case. No. 18-00057, US Ct. Int'l Trade (Apr. 5, 2018), available at https://www.cit.uscourts.gov/SlipOpinions/Slip_op18/18-37. pdf (last visited on Apr. 21, 2018).

$40 \quad$ Id. at 23.

41 Severstal, supra note 39 at 15.

42 Id.

43 Id. at 16 (re-cited from Corus Group v. ITC, 351 F.3d at 1359, Fed. Cir. (Dec. 11, 2003) as consistent with prior US Supreme Court rulings).

44 Severstal, supra note 39 at 18.

45 Id. 
had received the Commerce Department's report as required under the statute. ${ }^{46}$ The court, noting that plaintiffs had failed to challenge the validity of the Commerce Department's report itself, nevertheless determined that the President was limited to "action ... to adjust the imports of the article and its derivatives so that such imports will not threaten to impair the national security." that the tariffs were being "used in trade negotiations to draw concessions from other countries unrelated to steel imports" and that, as such, were not implemented to protect national security but rather to improve exports of unrelated industries, which, the court agreed "would raise a credible question as to whether the President misapprehended the authority granted by Section 1862." determined that the plaintiffs were unable to prove that the tariffs had been lifted in response to concessions by other countries benefitting unrelated industries. ${ }^{49}$ The court made this determination despite the fact that the tariffs had just been implemented and even though there was some evidence of a quid pro quo across industries. The following statement by the US Trade Representative Robert Lighthizer announcing the modification of the US-Korea Free Trade Agreement highlights such a case:

Today, Ambassador Lighthizer and Minister Kim are pleased to announce that the United States and the Republic of Korea have reached an agreement in principle on the general terms of amendments and modifications to the United States-Republic of Korea Free Trade Agreement ("KORUS FTA"). The nations have also agreed on terms for a country exemption for the Republic of Korea from tariffs imposed on steel imports under Section 232 of the Trade Expansion Act of 1962 pursuant to Presidential Proclamation 9705, as amended.

At the instruction of the Ministers, negotiators are finalizing the terms of the KORUS FTA negotiations, which are subject to domestic procedures in both nations before provisions can be brought into force. The revised agreement addresses issues related to investment, tariffs, trade in automobiles, and trade remedies. Additional progress was made in the areas of pharmaceuticals, customs and textiles to smoothly implement the KORUS FTA.

The arrangement with respect to steel imports is expected to take effect on May 1,

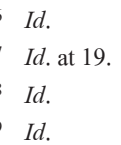


$2018 .^{50}$

When asked in a recent interview as to the efficacy of the steel tariffs to protect the steel industry and national security after the White House announced the exemptions for Korea, as well as Canada, Mexico, the EU and other major steel exporters, the US Treasury Secretary Steven Mnuchin admitted that the purpose of the tariffs was to negotiate better trade deals:

Well, Chris, I think ... the strategy has worked, quite frankly. So we announced the tariff. We said we were going to proceed. But, again, we said we'd simultaneously negotiate. And I'm pleased to say Ambassador Lighthizer reached a very productive understanding with South Korea, not just these tariffs, but on the [KORUS] trade agreement overall. We expect to sign that agreement soon.

And ... there is a quota. So, South Korea will reduce the amount of steel that they send into the United States as part of this. So I think this is an absolute win-win.

When I was at the G-20 last week, I had many discussions with-with my counterparts. So where we've put a pause on tariffs, we're negotiating. ${ }^{51}$

Regardless of the court's decision, considering the language of the statute, the statements made prior to and following passage of the tariffs, and the exemptions already granted, it is highly likely that litigation will continue to specifically target the national security rationale as a pre-text for gaining trade concessions in unrelated industries.

\section{International Legal Challenge}

In addition to litigation in the US courts, the steel and aluminum tariffs are certain to trigger WTO challenges for violating most-favored nation and national treatment

50 USTR, Joint Statement by the United States Trade Representative Robert E. Lighthizer and Republic of Korea Minister for Trade Hyun Chong Kim, Press Release, Mar. 2018, available at https://ustr.gov/about-us/policy-offices/pressoffice/press-releases/2018/march/joint-statement-united-states-trade (last visited on Apr. 21, 2018). [Emphasis added]

51 See Interview with Chris Wallace, Fox News Sunday, Mar. 26, 2018, available at http://www.foxnews.com/ transcript/2018/03/25/march-for-our-lives-organizers-send-message-to-congress.html (last visited on Apr. 21, 2018). 
provisions of GATT $1994 .^{52}$ The national security exemption in GATT Article XXI will likely be used by the US as a defense. Such a defense, which has been rarely used, would make it difficult to predict how the Dispute Settlement Body would interpret the provision and resolve the matter. On the one hand, the national security provision arguably should be interpreted narrowly so as not to undermine the entire purpose of the GATT by allowing members to gain trade concessions under the pre-text of its own broadly determined national security interests. For example, today the US claims that steel imports threaten its national security, while tomorrow China argues it is agriculture, thereby creating a slippery slope of tit-for-tat trade barriers. However, if Article XXI were interpreted narrowly and the US were to lose, this would play into the narrative of President Trump and his supporters that the US does not benefit from being a member of the WTO, which he recently called a 'disaster' for America. ${ }^{53}$

Predictably, China recently initiated consultations with the US pursuant to Article 4 of the DSU regarding the steel and aluminum tariffs. ${ }^{54}$ In addition to alleging a violation of MFN treatment for granting tariff exemptions for the above-listed countries and GATT Article X:3(a) for failing to administer its laws in a uniform, impartial and reasonable manner, China characterizes the tariffs not as a national security measure, but rather as an improper safeguard measure, in violation of GATT Article XIX, as well as several Articles in the Agreement on Safeguards. ${ }^{55}$ By alleging that the steel and aluminum tariffs are a de facto safeguard measure and not based on national security considerations, China will be allowed to apply "substantially equivalent concessions or other obligations under GATT" to the US per Article 8(2) of the Agreement on Safeguards, thereby creating additional legal uncertainty.

\section{Conclusion}

A reasonable argument can be made that the steel and aluminum tariffs are being

52 General Agreement on Tariffs and Trade 1994, Apr. 15, 1994, Marrakesh Agreement Establishing the World Trade Organization, Annex 1A, 1867 U.N.T.S. 187, 33 I.L.M. 1153 (1994), arts. I \& III.

53 C. Isidore, White House lauded US record with WTO, which Trump now calls a 'disaster,' CNN, Mar. 2, 2018, available at http://money.cnn.com/2018/03/02/news/economy/trump-wto-white-house-economic-report/index.html (last visited on Apr. 21, 2018).

54 Panel Report, Request for Consultations by China, United States - Certain Measures on Steel and Aluminum Products, WTO Doc. WT/DS544/1 (adopted Apr. 9, 2018), available at https://www.wto.org/english/tratop_e/dispu_e/cases_e/ ds544_e.htm (last visited on Apr. 21, 2018).

55 Id. 
used in trade negotiations to draw concessions unrelated to steel imports. One example is the renegotiation of the KORUS FTA, which involved revisions in automobiles, investment and textiles, among others, and which has been hailed as a success by senior members of the Trump administration. If proven, this could raise a credible question as to whether the President misapprehended the authority granted by Section 232, as noted by the Court of International Trade. The strategy of attacking the President's use of Section 232 in US courts has advantages over bringing a case before the WTO. One major advantage is that it does not feed into the political narrative of Donald Trump to undermine the authority of the WTO. The other is that it does not raise the risk of collateral damage to unrelated industries that will be affected by an escalating trade war. 